\title{
МІЖДИСЦИПЛІНАРНА ІНТЕГРАЦІЯ ЯК ФАКТОР УДОСКОНАЛЕННЯ ВИКЛАДАННЯ ФАРМАКОЛОГІЇ У МЕДИЧНОМУ ВИШ
}

\author{
Н. І. Волощук, О. С. Пашинська, А. О. Іваниця, І. В. Таран \\ Вінницький національний медичний університет імені М. I. Пирогова
}

\section{INTERDISCIPLINARY INTEGRATION AS AN IMPROVING FACTOR OF TEACHING PHARMACOLOGY IN MEDICAL UNIVERSITIES}

\author{
N. I. Voloshchuk, O. S. Pashynska, A. O. Ivanytsia, I. V. Taran \\ M. Pyrohov Vinnytsia National Medical University
}

\begin{abstract}
У статті розглянуті роль та місце міждисциплінарної інтеграції як фактора удосконалення викладання на кафедрі фармакології Вінницького національного медичного університету ім. М. І. Пирогова. Міждисциплінарні зв'язки допомагають доповнити зміст однієї дисципліни знаннями з іншої, об'єднують їх і забезпечують формування професійно важливих вмінь та навичок. Застосування міждисциплінарних технологій підготовки лікаря дозволяє підняти його на якісно новий рівень клінічного мислення, здатного комплексно вирішувати завдання медичної практики на основі широкого інтегрування даних різноманітних дисциплін.

The role and place of interdisciplinary integration are considered in this article as a factor of improving teaching at the Department of Pharmacology in M. Pyrohov Vinnytsia National Medical University. Interdisciplinary connections help to supplement the content of knowledge in one discipline from another, combine them and ensure formation of professionally important skills and abilities. The use of interdisciplinary technologies of doctor's training allows to rise him on a new level of clinical thinking. This makes him able to solve tasks of medical practice comprehensively, basing on extensive data integration of different disciplines.
\end{abstract}

Вступ. Якість професійної освіти є найважливішим питанням розвитку сучасної освіти. Процес реформування сучасної професійної освіти України актуалізує проблему підвищення якості додипломної та післядипломної підготовки лікарів [1].

Основне завдання, яке держава ставить перед будь-яким вищим навчальним закладом, - це провадження освітньої діяльності на високому рівні, що забезпечить здобуття особами вищої освіти відповідного ступеня за обраними спеціальностями [2].

Нині провідною метою навчального процесу у вищому медичному закладі є формування особистості лікаря, який уміє сприймати необхідну інформацію, самостійно здобувати і використовувати її на практиці, вирішувати складні клінічні завдання [3]

Зростання науково-технічного потенціалу суспільства, розширення теоретичної бази, накопичення емпіричного матеріалу об’єктивно приводить до диференціації наукового знання, появи все нових і нових наукових дисциплін. Водночас не менш швидкими темпами зростає потреба в інтеграції науко-

(ㄱ Н. І. Волощук, О. С. Пашинська, А. О. Іваниця, І. В. Таран вого знання. Це призводить до однієї з центральних суперечностей сучасної освіти - “необхідністю забезпечити високий рівень інтеграції професійних знань слухачів на тлі прискорення диференціації навчальних дисциплін” [4].

Проблема міждисциплінарної інтеграції в освіті вивчалася давно. Відсутність, ненауковість чи недостатність глибини міждисциплінарної інтеграції часто призводили, з одного боку, до дублювання окремих питань у різних науках в умовах дефіциту навчального часу, а з іншого - до недостатнього засвоєння студентами низки тем у дисциплінах [5].

Основна частина. Міждисциплінарна інтеграція - це цілеспрямоване посилення міждисциплінарних зв'язків за умов збереження теоретичної i практичної цілісності навчальних дисциплін.

Методологічною основою міждисциплінарної інтеграції $є$ інтегративний підхід у професійній освіті, сутність якого обгрунтована в працях Л. Демінської. Водночас міждисциплінарна інтеграція це процес узгодження змісту навчальних дисциплін щодо відображення ними єдиних, безперервних і цілісних явищ професійної діяльності. 
Інтеграція навчального процесу у вищих медичних закладах передбачає його побудову за принципом логічних узагальнень послідовності програмних дисциплін і “комплексування” навчання. Викладання проводиться так, щоб знання однієї дисципліни були фундаментом для вивчення іншої. Методичне опрацювання змісту навчальних предметів полягає в систематизації та узагальненні матеріалу, отриманого при вивченні різних дисциплін [6].

Реалізація міждисциплінарних зв’язків у навчальній діяльності - це один із необхідних дидактичних засобів формування в студентів професійних знань і навичок. Важливо, щоб навчальна інформація, засвоєна під час вивчення інших дисциплін, не повторювалась, а використовувалася для мотивації навчальної діяльності студентів, актуалізації опорних знань, умінь і навичок, обгрунтування, з’ясування сутності явищ, моделювання процесів тощо [7].

У зв’язку з прогресуючим розвитком системного підходу до розуміння природи людського організму, шляхів діагностики і лікування значно зросли вимоги до ефективності міждисциплінарної інтеграції. В педагогічній літературі описані внутрішньодисциплінарна, міждисциплінарна інтеграція, вертикальна, горизонтальна та універсальна інтеграція. Горизонтальна інтеграція пропонує в рамках однієї дисципліни вивчення проблем або рішення практично-орієнтовних завдань, які одночасно знаходяться в предметному полі двох або трьох дисциплін; знаходження загального змісту та способів цілісного бачення проблеми, що вивчається, методів її вирішення і шляхів впровадження результатів. Перевага горизонтальної інтеграції полягає в тому, що головним елементом цієї технології навчання стають об’єкти майбутньої лікарської діяльності. Власне цілісний організм людини, його функціональні системи, органи в стані норми і патології є тими об’єктами, навколо яких об’єднуються в модулі навчальні дисципліни з метою міждисциплінарного вивчення цих систем. Вертикальна інтеграція доповнює горизонтальну і має на меті включення в зміст навчальних дисциплін низки науково-прикладних проблем, які проходять весь навчальний матеріал, надають йому високий рівень інтеграції. В ході вертикальної інтеграції вирішуються не вузькопредметні професійні завдання, а міждисциплінарні проекти, до вирішення яких долучаються численні дисципліни [8].

Формуванню наукових понять на міждисциплінарній основі сприяють педагогічні, загальнодидактичні і психологічні умови:
1) узгоджене в часі вивчення окремих навчальних дисциплін, при якому кожна з них спирається на попередню понятійну базу і готує тих, хто навчається, до успішного засвоєння понять наступної дисципліни;

2) необхідність забезпечення наступності та послідовності в розвитку понять; ті поняття, які є спільними для ряду дисциплін, повинні весь час розвиватись, наповнюватись новим змістом, збагачуватись новими зв’ язками;

3) спільність в інтерпретації загальнонаукових понять;

4) виключення дублювання одних і тих самих понять під час вивчення різних предметів;

5) забезпечення єдиного підходу до розкриття однакових наукових понять [9].

Значення фармакології для медичної освіти загалом важко переоцінити. Вона тісно пов'язана 3 дисциплінами, які вивчають студенти медичних навчальних закладів на перших трьох курсах, і $є$ базою для навчання на клінічних кафедрах. Лікарський засіб, який є об’єктом її вивчення, діє на різні структури через певні біохімічні механізми, змінюючи функцію органів і систем із метою ï̈ нормалізації. Розуміння цих складних процесів потребує фундаментальних знань багатьох предметів. Викладання фармакології як обов’язкової складової успішного вивчення медичних наук вимагає конкретних заходів для оптимізації її засвоєння студентами.

Так, спираючись на наш багаторічний досвід викладання дисципліни, на основі цілеспрямованого, теоретично і технологічно обгрунтованого відбору структурних елементів змісту, були виявлені системоутворюючі зв’ язки навчальної дисципліни “Фармакологія” та інших дисциплін медичного вишу, 3 якими фармакологія пов'язана “вертикальними” інтеграційним зв’язками. Серед них, насамперед, латинська мова, анатомія людини, біологія, загальна та біологічна хімія, нормальна фізіологія. До кафедр з відносною вертикальною інтеграцією (в межах окремих тем та розділів) можна віднести гістологію, мікробіологію, історію медицини, біофізику, філософію тощо.

Якщо розглядати значення фармакології для опанування предметів, які вивчають студенти на старших курсах, можна беззаперечно стверджувати про тісні інтеграційні зв'язки з усіма без винятку дисциплінами, адже жодний патологічний стан не обходиться на сьогодні без відповідної фармакологічної корекції. 
Одним із предметів, з якими у фармакології існує тісний інтегративний горизонтальний зв’язок у процесі навчання на III курсі, - це патологічна фізіологія. Розуміння основних понять та сутності патологічних процесів у різних системах, органах i тканинах хворої людини, знання та розуміння патоморфологічних змін зумовлює правильне розуміння механізмів та точок прикладання дії різних лікарських засобів, що дозволяє студенту мінімізувати механічне запам’ятовування фармакодинаміки лікарських препаратів на користь логічного розуміння можливих сфер застосування та небажаних реакцій препаратів кожної конкретної групи.

Між тим загальноосвітня практика вишів переконливо свідчить, що проблема реалізації міждисциплінарної інтеграції ще далека від свого остаточного вирішення. До основних проблем реалізації горизонтальної міждисциплінарної інтеграції для ефективного формування інформаційно-комунікаційної компетентності студентів можна віднести:

- методичну та інформаційно-технологічну непідготовленість окремих викладачів;

- різний підхід і відношення викладачів кафедр до формування професійно-значущих знань, умінь та навичок;

- небажання окремих викладачів використовувати в свої профілючих дисциплінах знання, уміння та навички, набуті студентами при вивченні інших дисциплін.

До можливих шляхів усунення цих проблем, на нашу думку, можна віднести загально-педагогічні (спеціальні курси підвищення кваліфікації викладацького складу), а також такі, що можуть бути реалізовані на рівні методичних рад навчальних закладів. Сюди відносять:

- узгодження і перерозподіл тем навчальних програм відповідних дисциплін як за змістом, так і за часовими параметрами;

- створення міждисциплінарних проектів;

- організація і впровадження різноманітних методів і форм організації освітнього процесу (інтегровані заняття, тематичні семінари, олімпіади і студентські наукові конференції, ділові ігри, сумісні засідання наукових гуртків тощо).

Набувши необхідні вміння та навички, студенти мають можливість комплексного бачення підходів до розгляду проблем реальної дійсності, в тому числі при рішенні майбутніх професійних задач. Практика показує, що педагогічна взаємодія викладачів різних навчальних дисциплін з метою реалізації горизонтальної МДІ сприяє більш ефек- тивному формуванню інформаційно-комунікаційної компетентності студентів, оскільки розширяє їх освітні можливості, дозволяє застосовувати їх у нових умовах, що розвиває врешті-решт їх професійне мислення. Результати інтегрованого навчання сприяють цілісному розвитку особистості майбутнього спеціаліста, його системного, творчого мислення і бачення професійної діяльності, сприяють інтенсифікації, систематизації, оптимізації навчально-пізнавальної діяльності студентів.

Робота щодо здійснення міжпредметних зв’ язків повинна проводитись не час від часу, а систематично, цілеспрямовано. Міждисциплінарна інтеграція - вимога часу. Ї̈̈ значення зростає в сучасних умовах організації навчального процесу в медичних навчальних закладах, коли все менше часу відводиться на аудиторні заняття з фармакології та інших предметів, що унеможливлює дублювання окремих питань у межах вивчення різних предметів, а з іншого боку, недостатня глибина міждисциплінарної інтеграції веде до недостатнього засвоєння студентами ряду тем з дисципліни, знання яких є необхідним у подальшому.

Інтеграція наукових знань здійснюється на основі міждисциплінарних та внутрішньодисциплінарних зв'язків і являє собою логічно завершену структуру багатодисциплінарного знання. Така інтеграція не просто доповнює зміст однієї дисципліни знаннями з іншої, а об’єднує їх і забезпечує не вузькодисциплінарну підготовку, а діяльність, яка формує професійно важливі вміння, навички та особистісні якості.

Висновки. Таким чином, міждисциплінарна інтеграція - це необхідна складова підготовки майбутнього фахівця. Застосування міждисциплінарних технологій підготовки лікаря дозволяє підняти його на якісно новий рівень клінічного мислення, здатного комплексно вирішувати завдання медичної практики на основі широкого інтегрування даних різноманітних дисциплін.

Для вирішення основних завдань міждисциплінарної інтеграції важливі послідовність і систематичність при вивченні теоретичних і клінічних дисциплін.

Системний підхід до викладання основ медичних знань, адаптація поданого матеріалу у доступній для широкого загалу студентів формі, використання методів активного навчання, впровадження сучасних інформаційних технологій є основним напрямком роботи викладачів кафедри фармакології Вінницького національного медичного університету. 


\section{Список літератури}

1. Левківський К. М. Про стан і перспективи розвитку вищої освіти в Україні : доповідь на парламентських слуханнях / К. М. Левківський. - К. : Парлам. вид-во, 2004. - 184 c.

2. Закон України “Про вищу освіту” від 01.07.2014 р. № 1556-VII (редакція станом на 01.07.2014 р.). - zakon. rada.gov.ua.

3. Міждисциплінарна інтеграція викладання біоорганічної хімії в медичному університеті / Е. Ю. Рождественський, М. С. Сидун, А. Г. Кривобок [та ін.] // Акт. пробл. суч. медицини: Вісн. Укр. мед. стоматол. академії. - 2009. - Т. 9, вип. 4 (ч. 3). - С. 249-251.

4. Іванова Л. І. Сучасні підходи до професійної підготовки майбутнього вчителя фізичної культури / Л. І. Іванова // Педагогічний процес: теорія і практика : зб. наук. пр. - К. : Міленіум, 2006. - Вип. 1. - С. 63-73.

5. Петунин О. В. Теоретические основы подготовки студентов к профессиональной деятельности учителя физической культуры : автореф. дисс. д-ра пед. наук: 13.00.04 / О. В. Петунин. - СПб., 1996. - 48 с.

6. Демінська Л. О. Міждисциплінарні зв’язки у процесі професійної підготовки майбутніх учителів фізичної культури : дис. ... канд. пед. наук: 13.00.04 / Л. О. Демінська. - Донецьк, 2004. - 245 с.

7. Микитюк О. Ю. Міжпредметна інтеграція при вивченні медичної і біологічної фізики як фактор формування наукового світогляду майбутнього лікаря / О. Ю. Микитюк, В. Ф. Боєчко, О. І. Олар // Кредитномодульна система організації навчального процесу у вищих медичних (фармацевтичному) навчальних закладах України на новому етапі : матеріали доп. Х ювіл. Всеукр. навч.-наук. конф. з міжнар. участю,18-19 квіт. 2013 р. Тернопіль : ТДМУ, 2013. - Ч. 2. - С. 602-604.

8. Прошкін В. В. Інтеграція університетської науки й освіти: історичний аспект [Електронний ресурс] / В. В. Прошкін // е-журнал “Педагогічна наука: історія, теорія, практика, тенденції розвитку”. - 2010. - № 2. Режим доступу : http://intellect-invest.org.ua/pedagog_ editions_e-magazine_pedagogical_science_vypuski_ n2_2010_st_1/.

9. Чебышев Н. Основа развития современной высшей школы / Н. Чебышев, В. Каган // Высшее образование в России. -1998. - № 2. - С. 17-22. 